\title{
Properties of isolated human islets of Langerhans: insulin secretion, glucose oxidation and protein phosphorylation
}

\author{
D. E. Harrison ${ }^{1}$, M. R. Christie ${ }^{1}$ and D.W. R. Gray ${ }^{2}$ \\ ${ }^{1}$ Nuffield Department of Clinical Biochemistry and ${ }^{2}$ Nuffield Department of Surgery, John Radcliffe Hospital, Oxford, UK
}

\begin{abstract}
Summary. In the present study, human islets were isolated by collagenase digestion from the pancreases of three kidney donors. Maintainance of the islets in tissue culture enabled insulin release, glucose oxidation and $\mathrm{Ca}^{2+}$-calmodulin-dependent protein phosphorylation to be determined using the same islets. Increasing glucose over a range $0-20 \mathrm{mmol} / 1 \mathrm{re}-$ sulted in a sigmoidal stimulation of insulin release $(28.8 \pm$ 5.2 to $118.4 \pm 25.8 \mu \mathrm{U} \cdot$ islet $^{-1} \cdot \mathrm{h}^{-1}, n=10$; threshold $<$ $4 \mathrm{mmol} / \mathrm{l}$ ). There was a marked correlation between the insulin secretory response of the islets to glucose and their rate of glucose oxidation $(5.9 \pm 0.3$ at glucose $2 \mathrm{mmol} / \mathrm{l}$ up to $25.8 \pm$ $1.8 \mathrm{pmol} \cdot$ islet $^{-1} \cdot \mathrm{h}^{-1}$ at $\left.20 \mathrm{mmol} / \mathrm{l}, r=0.98\right)$. $\mathrm{N}$-acetylglucosamine $(20 \mathrm{mmol} / \mathrm{l})$ failed to elicit a secretory response from the islets. Stimulation of insulin secretion by glucose was de-
\end{abstract}

pendent upon the presence of extracellular $\mathrm{Ca}^{2+}$. Extracts of the islets contained a $\mathrm{Ca}^{2+}$-calmodulin-dependent protein $\mathrm{ki}$ nase which phosphorylated a 48-kdalton endogenous polypeptide. Myosin light-chain kinase activity was demonstrated in the presence of exogenous myosin light chains. This report demonstrates for the first time the sigmoidal nature of glucose-stimulated insulin release from isolated human islets, and its correlation with enhanced glucose oxidation. Furthermore, this is the first report of the presence of $\mathrm{Ca}^{2+}$-dependent protein kinases in human islets.

Key words: Human islets, insulin secretion, glucose oxidation, $\mathrm{Ca}^{2+}$-calmodulin, protein kinases.
Very few biochemical studies on isolated human islets of Langerhans have been performed, yet such studies are essential in validating the application of models for insulin secretion, obtained from studies on animal islets, to the human islet. In the present study, three separate preparations of human islets were obtained after collagenase digestion of pancreatic tissue from three renal transplant donors. Maintainance of the islets in tissue culture enabled several experiments to be performed on each preparation of islets.

\section{Materials and methods}

\section{Preparation and maintenance of islets}

Islets were isolated from the pancreases of two female and one male renal transplant donors (aged 38,52 and 31 years, respectively). Causes of death were diagnosed as an intracranial arteriovenous malformation (donor 1 ) and subarachnoid haemorrhages (donors 2 and 3 ). The islets were isolated by a collagenase digestion method as described previously [1]. Briefly, the pancreas was distended by injection of medium $(1 \mathrm{ml} / \mathrm{g}$ of tissue) containing collagenase $(6 \mathrm{mg} / \mathrm{ml}$, Type I, Sigma, Poole, Dorset, UK) into the pancreatic duct. After incubation at $39^{\circ} \mathrm{C}$ for $23 \mathrm{~min}$ the gland was rapidly cooled and distended by in- jection of cold medium $(1 \mathrm{ml} / \mathrm{g})$ into the pancreatic duct. The pancreas was dispersed by a process of teasing and shaking and the dispersed tissue collected by centrifugation at $50 \mathrm{~g}$ for $10 \mathrm{~s}$. The pellet was resuspended in medium and further dispersed by gentle aspiration and expulsion through a 14 gauge needle (three times) and a 16 gauge needle (once). The tissue suspension was then passed through a nylon mesh filter (pore size $106 \mu \mathrm{m}$ ). Tissue trapped in the filter was carefully washed and passed through a polyester mesh filter (pore size $500 \mu \mathrm{m}$ ). The trapped tissue was discarded and isolated islets were individually collected from the filtrate, using a wire loop. All stages of the preparation were performed in Hank's balanced salt solution (Flow Laboratories, Irvine, Ayrshire, UK), containing glucose $(5 \mathrm{mmol} / \mathrm{l})$. With the exception of that used to inject the collagenase, the medium also contained bovine serum albumin $(4 \mathrm{~g} / 1$, Fraction $\mathrm{V}$, Sigma).

Islets (approximately 700/donor) were maintained in tissue culture medium in 5-ml Petri dishes. The culture medium was RPMI 1640 (Gibco Europe, Paisley, UK) containing glucose $(11 \mathrm{mmol} / \mathrm{l})$, penicillin $(0.1 \mathrm{mg} / \mathrm{ml})$, streptomycin $(0.1 \mathrm{mg} / \mathrm{ml})$ and $10 \%(\mathrm{v} / \mathrm{v})$ heat-inactivated fetal calf serum (Gibco Europe). Islets were cultured at $37^{\circ} \mathrm{C}$ in a humidified atmosphere of air: $\mathrm{CO}_{2}$ $(95 \%: 5 \%)$.

\section{Insulin secretion}

Batches of five islets were incubated for $2 \mathrm{~h}$ at $37^{\circ} \mathrm{C}$ in $0.6 \mathrm{ml}$ bicarbonate-buffered medium [2], containing bovine serum albumin $(2 \mathrm{mg} /$ 

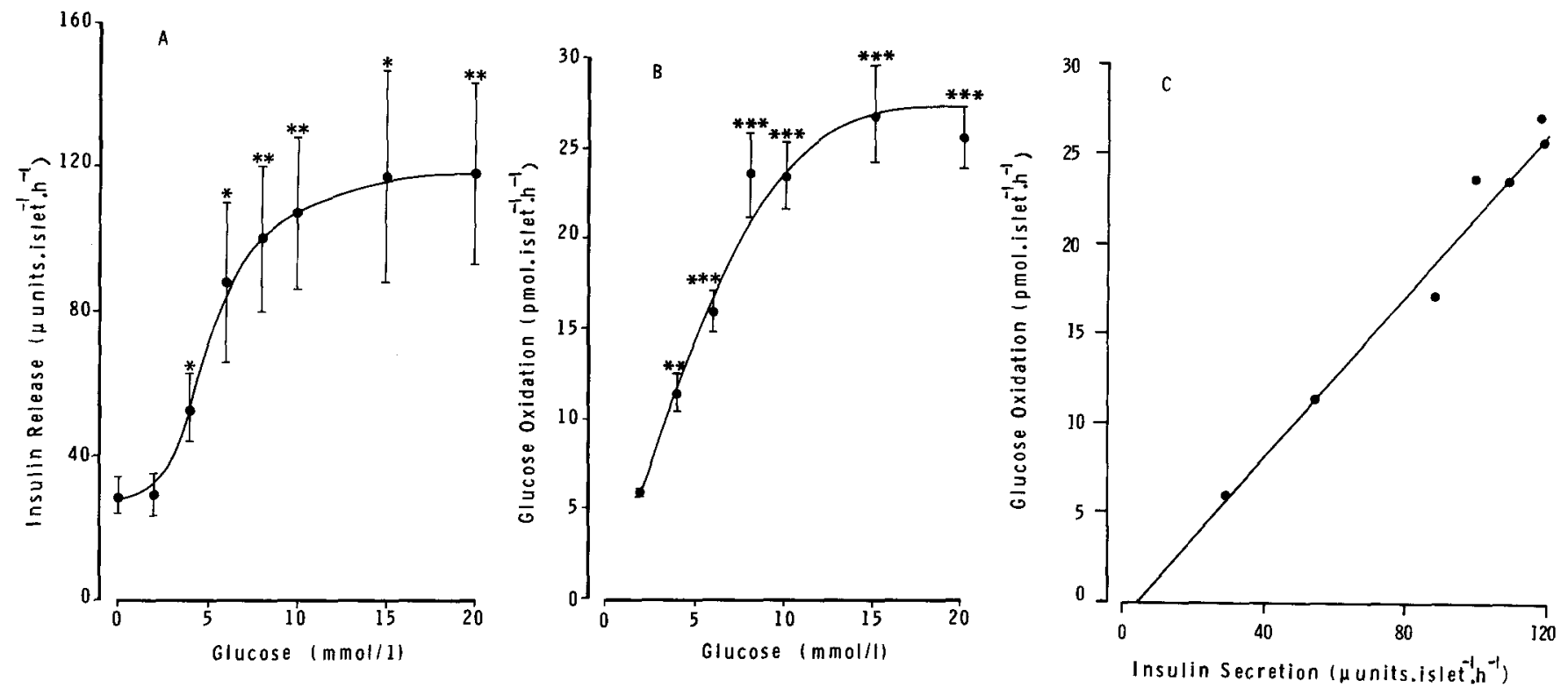

Fig. 1 A-C. Correlation between insulin secretion and glucose oxidation by isolated human islets of Langerhans. After overnight culture, A rates of insulin secretion $(n=10)$ and $\mathbf{B}$ glucose oxidation $(n=6-8)$ by batches of islets were measured over a range of glucose concentrations as described in the Methods. $C$ shows the correlation between rates of insulin release and glucose oxidation at each glucose concentration used $(r=0.98) .{ }^{* *} \mathrm{p} \leqslant 0.001,{ }^{* *} \mathrm{p} \leqslant 0.01, * \mathrm{p} \leqslant 0.05$, for values significantly different from those obtained at glucose $2 \mathrm{mmol} / 1$.

$\mathrm{ml})$ and gassed with $\mathrm{O}_{2}: \mathrm{CO}_{2}(95 \%: 5 \%)$. The concentrations of glucose and other additions are described in the Results section. After incubation, samples of medium were removed, diluted in phosphate buffer $(40 \mathrm{mmol} / 1, \mathrm{pH} 7.4)$ containing albumin $(1 \mathrm{~g} / 1)$ and merthiolate $(6 \mathrm{mmol} / \mathrm{l})$ and stored at $-20^{\circ} \mathrm{C}$ until assayed for insulin; the islets were replaced in tissue culture medium. Insulin was measured by radioimmunoassay [3] using rat or human insulin as standard. Under the conditions used, comparable results were obtained with either standard.

\section{Glucose oxidation}

Batches of six islets were incubated for $90 \mathrm{~min}$ in $20 \mu \mathrm{l}$ bicarbonatebuffered medium containing bovine serum albumin $(2 \mathrm{mg} / \mathrm{ml})$ and gassed with $\mathrm{O}_{2}: \mathrm{CO}_{2}(95 \%: 5 \%)$. D-[U- $\left.{ }^{14} \mathrm{C}\right]$ glucose (Amersham International, Amersham, Bucks., UK; sp. act. $3.5 \mathrm{dpm} / \mathrm{pmol}$ ) was present in a range of concentrations from 2 to $20 \mathrm{mmol} / \mathrm{l}$. Rates of glucose oxidation were estimated by measuring ${ }^{14} \mathrm{CO}_{2}$ production as described previously [4].

\section{Protein phosphorylation}

After 2 or 4 days in culture, islets were collected in $100 \mu 1$ Hepes buffered medium and were washed once in buffer composed of sucrose $(0.25 \mathrm{~mol} / 1)$, Tris $(3 \mathrm{mmol} / 1)$ and dithiothreitol $(1 \mathrm{mmol} / 1)$, $\mathrm{pH}$ 7.4. Islets were resuspended in $50 \mu \mathrm{l}$ of this buffer and were sonicated $(3 \times 3$ s) using a Dawe Soniprobe (Dawe Instruments, London, UK). The supernatant fraction obtained after centrifugation of the sonicate for $30 \mathrm{~min}$ at $190,000 \mathrm{~g}$ was diluted and used for assay. Phosphorylation reactions were carried out at $30^{\circ} \mathrm{C}$ for 1 or $2 \mathrm{~min}$. The reaction mixture (final volume $25 \mu \mathrm{l}$ ) contained $10 \mu \mathrm{l}$ islet extract (equivalent to 16 islets), imidazole $(24 \mathrm{mmol} / 1$; $\mathrm{pH} 7.0)$, dithiothreitol $(1 \mathrm{mmol} / 1)$, $\mathrm{MgCl}_{2}(1 \mathrm{mmol} / \mathrm{l}),\left[\gamma^{3}{ }^{32} \mathrm{P}\right] \mathrm{ATP}(33 \mu \mathrm{mol} / \mathrm{l})$ (sp. act. $6-7 \mathrm{dpm} / \mathrm{fmol}$; Amersham International) and the following additions as appropriate: $\mathrm{CaCl}_{2}(10 \mu \mathrm{mol} / \mathrm{l})$, EGTA $(1 \mathrm{mmol} / \mathrm{l})$, calmodulin $(1.25 \mu \mathrm{mol} / \mathrm{l})$, trifluoperazine $(100 \mu \mathrm{mol} / \mathrm{l})$, myosin light chains $(2 \mu \mathrm{g})$. Reactions were started by addition of $\left[\gamma_{-}{ }^{32} \mathrm{P}\right] \mathrm{ATP}$ and terminated by addition of $15 \mu 1$ SDS stop (SDS (sodium dodecyl sulphate) $3.75 \% \mathrm{w} / \mathrm{v}$, Tris $\mathrm{HCl}$ $20 \mathrm{mmol} / 1$ (pH 6.8), bromophenol blue $0.02 \% \mathrm{~W} / \mathrm{v}$, glycerol $5 \% \mathrm{v} / \mathrm{v}$ ) solution and boiling for $5 \mathrm{~min}$. After cooling, $2.5 \mu \mathrm{l} 2$-mercaptoetha- nol were added to each tube. $\left[{ }^{32} \mathrm{P}\right]$-labelled proteins were separated by electrophoresis in 16\% SDS-polyacrylamide gels as described previously [5] except that AcrylAide (Miles, Slough, Bucks, UK) replaced bisacrylamide as cross-linking reagent and was used in the ratio acrylamide: AcrylAide 32:1 by weight. Phosphoproteins were detected by autoradiography using Kodak X-Omat AR-5 film as described previously [6].

\section{Statistical analysis}

All results are expressed as mean \pm SEM for the number of batches of islets stated. The significance of differences from control values obtained in the same experiments was assessed using Student's t-test.

\section{Results}

After overnight culture, the islets responded to an increase in glucose concentration over the range $0-20 \mathrm{mmol} / 1$ with a sigmoidal increase in insulin release. Figure $1 \mathrm{a}$ shows the combined values obtained for two individual islet preparations. There was a marked correlation between the insulin secretory response of the islets to glucose and their rate of glucose oxidation ( $r=0.98$, Figs. $1 \mathrm{~b}$ and $\mathrm{c}$ ). Half-maximal values for insulin release and glucose oxidation occurred at a glucose concentration of approximately $5 \mathrm{mmol} / 1$. The threshold concentration of glucose required for stimulation of insulin release was between 2 and $4 \mathrm{mmol} / \mathrm{l}$. To assess whether tissue culture might have affected the secretory response of the islets, control experiments were performed using rat islets cultured under identical conditions. Thus, insulin release was stimulated 15 -fold when glucose was increased from 2 to $20 \mathrm{mmol} / 1$ (from $14.9 \pm 4.7$ to $222.4 \pm 17.4 \mu \mathrm{U} \cdot$ islet $^{-1}$. $\left.\mathrm{h}^{-1}, p \leqslant 0.001, n=10\right)$ with half-maximal stimulation 
Table 1. Effect of various agents on insulin secretion from human islets

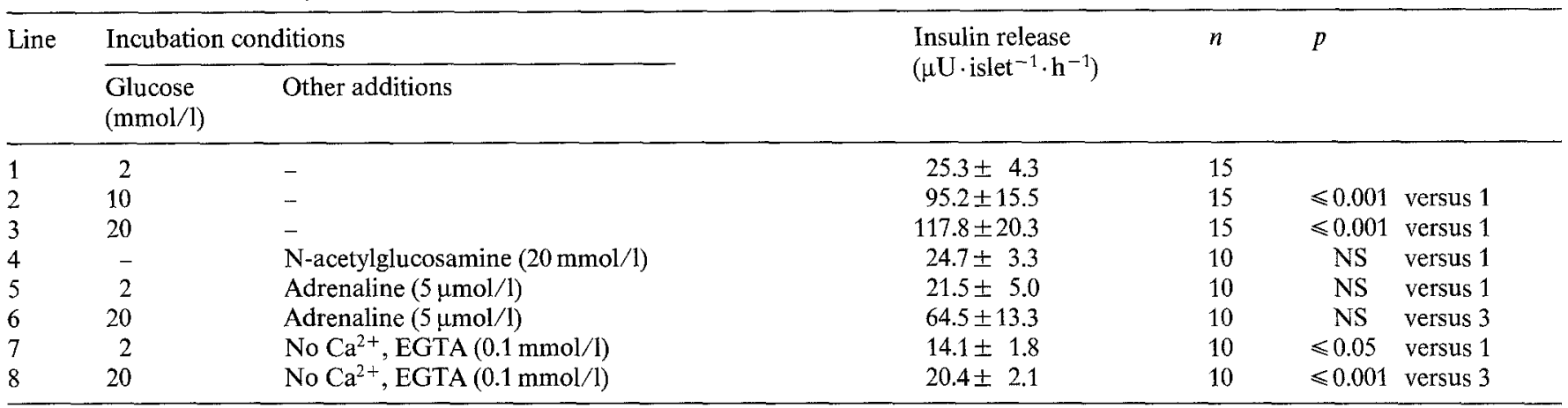

Rates of insulin secretion from isolated human islets were measured after overnight culture as described in the Methods. Values given are mean $\pm S E M$ for the number of observation (n) shown

occurring at $8.4 \mathrm{mmol} / \mathrm{l}$. In these experiments, no significant stimulation of insulin secretion occurred at $6 \mathrm{mmol} / 1$ glucose $\left(28.7 \pm 9.6 \mu \mathrm{U} \cdot\right.$ islet $\left.^{-1} \cdot \mathrm{h}^{-1}, n=10\right)$. These results are comparable to previously-reported values for fresh rat islets [7].

The effects of various agents on insulin secretion by the human islets are shown in Table 1 . As previously reported [8], $\mathrm{N}$-acetylglucosamine $(20 \mathrm{mmol} / \mathrm{l})$ failed to stimulate insulin release. Although not statistically significant, adrenaline $(5 \mu \mathrm{mol} / 1)$ decreased insulin release in the presence of glucose $(20 \mathrm{mmol} / \mathrm{l})$, while basal insulin release (glucose $2 \mathrm{mmol} / \mathrm{l}$ ) was only slightly decreased. Removal of $\mathrm{Ca}^{2+}$ from the incubation medium completely abolished glucose-stimulated insulin release $(p \leqslant 0.001)$ and caused a small decrease in basal insulin secretion $(p \leqslant 0.05)$.

After 2 or 4 days in culture, extracts of the islets were prepared and examined for $\mathrm{Ca}^{2+}$-calmodulin-dependent protein kinase activity. Figure 2 shows that incubation of islet extracts in the presence of $\left[\gamma-{ }^{32}\right.$ P]ATP and in the absence of $\mathrm{Ca}^{2+}$, resulted in phosphorylation of several protein bands (channel1). Addition of $\mathrm{Ca}^{2+}$ markedly stimulated phosphorylation of a polypeptide of molecular weight of 48,500 $700(n=4)$ (channel 2). Calmodulin (channel 3) further enhanced this phosphorylation, while the calmodulin antagonist trifluoperazine completely abolished the stimulatory effects of $\mathrm{Ca}^{2+}$ and calmodulin (channel 4). A further $\mathrm{Ca}^{2+}$-calmodulin-dependent protein kinase was demonstrated by the addition of myosin light chains. Phosphorylation of myosin light chains seen in the presence of $\mathrm{Ca}^{2+}$ (channel 5) was stimulated by the addition of calmodulin (channel 6); this stimulation was reduced in the presence of trifluoperazine (channel 7). This suggests the presence of a $\mathrm{Ca}^{2+}$-calmodulin-dependent myosin light chain kinase.

\section{Discussion}

The absolute rates of insulin release reported here are greater than those reported previously [8-10]. Possible

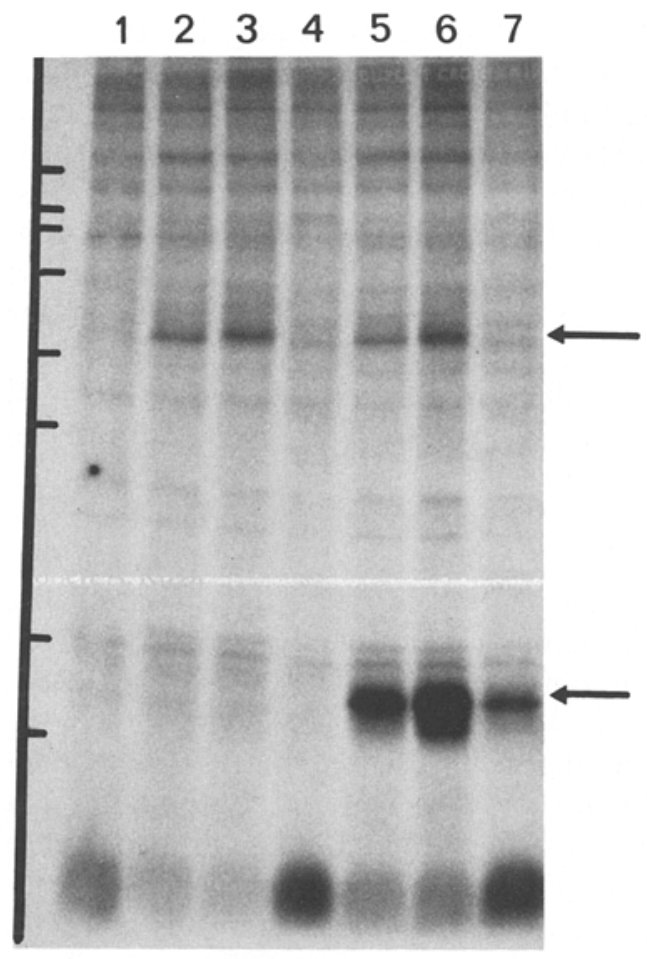

Fig. 2. Autoradiogram showing the effect of $\mathrm{Ca}^{2+}$ and calmodulin on protein phosphorylation catalysed by extracts of human islets. Human islet extracts were incubated with $\left[\gamma-{ }^{32}\right.$ P]ATP and the following additions as described in the Methods: channel 1, EGTA $(1 \mathrm{mmol} / 1)$; channels 2 and $5, \mathrm{Ca}^{2+}(10 \mu \mathrm{mol} / 1)$; channels 3 and $6, \mathrm{Ca}^{2+}$ and calmodulin $(1.25 \mu \mathrm{mol} / 1)$; channels 4 and $7, \mathrm{Ca}^{2+}$, calmodulin and trifluoperazine $(100 \mu \mathrm{mol} / 1)$. In addition, channels 5-7 contained myosin light chains $(2 \mu \mathrm{g})$. After separation by SDS-polyacrylamide gel electrophoresis, phosphorylated proteins were detected by autoradiography. The upper and lower arrows indicate the positions of the endogenous $48 \mathrm{kDal}$ polypeptide and of myosin light chains respectively. The mobilities of standard proteins are shown on the left hand side of the autoradiograph. Their molecular weights, in descending order were: $98,88,66,57,43,35,20$, and $14 \mathrm{kDal}$.

explanations for the increased rate of insulin release may include the relatively large size of the islets employed in this study $(106-500 \mu \mathrm{m})$ or an improved method for islet preparation - the islets produced by this method were essentially free of exocrine tissue as determined 
by microscopic and histological examination (data not shown). This may have improved their survival in tissue culture. Lohmann et al. [11] reported elevated values for insulin release from isolated islets of certain subjects with maturity-onset diabetes. This could not explain the present results, since the donors of the pancreases used in the present study had no history of diabetes.

Although the results presented are derived from only three preparations of human islets, we felt it useful to report them in view of the scarcity of data regarding human islets. In general, the main features provide encouraging support for the view that models derived from rodent islets may be applicable to man. Thus, the data show a strong correlation between rates of insulin secretion in response to glucose and rates of glucose oxidation. This is as would be expected from the substrate-site hypothesis [12]. An interesting difference between the human and rodent islet is the slightly lower glucose threshold $(4 \mathrm{mmol} / \mathrm{l})$ for stimulation of insulin release displayed by the human islet. This does not appear to be an artefact due to the effect of culturing the islets, since for rat islets cultured under the same conditions, stimulation of insulin secretion required glucose concentrations in excess of $6 \mathrm{mmol} / 1$. These observations are consistent with the observation that fasting plasma glucose concentrations in man are lower $(3-4 \mathrm{mmol} / \mathrm{l})$ [13] than in rodents $(5.3 \mathrm{mmol} / \mathrm{l})$ [3]. Another difference between human and rodent islets is the failure of human islets to respond to $\mathrm{N}$-acetylglucosamine. This confirms a previous report for human islets [8] but is in marked contrast to rodent islets [14]. On the basis of the substrate-site hypothesis [12], it would be predicted that human islets are not able to metabolise $\mathrm{N}$-acetylglucosamine.

Glucose-stimulated insulin secretion is dependent upon extracellular $\mathrm{Ca}^{2+}[15]$. Thus, our observation that $\mathrm{Ca}^{2+}$ is required for glucose to stimulate insulin release from human islets (Table 1) is consistent with the hypothesis that $\mathrm{Ca}^{2+}$ plays a key role in stimulus-secretion coupling in the $\beta$-cell. The nature of the intracellular coupling system(s) for $\mathrm{Ca}^{2+}$ is currently a subject of intense research. Studies showing the inhibitory effect of phenothiazine drugs on insulin secretion from rat islets were originally taken to implicate calmodulin as a mediator for $\mathrm{Ca}^{2+}$ in the mechanism of stimulus-secretion coupling in the rodent pancreatic $\beta$-cell $[16,17]$. In addition, it has been suggested [6] that the $\mathrm{Ca}^{2+}$-calmodulin complex may activate specific protein kinase(s) which in turn would activate the exocytotic release apparatus. However, more recently, the phenothiazine drugs have been shown to inhibit $\mathrm{Ca}^{2+}$-phospholipid-dependent protein kinase [18]. It is therefore possible that both the $\mathrm{Ca}^{2+}$-calmodulin-dependent- and $\mathrm{Ca}^{2+}$-phospholipiddependent protein kinases contribute to the exocytotic release process. Studies have shown that rat pancreatic islets contain $\mathrm{Ca}^{2+}$-phospholipid-dependent protein $\mathrm{ki}^{-}$ nase [19], $\mathrm{Ca}^{2+}$-calmodulin-dependent myosin light chain kinase [20-22] and a $\mathrm{Ca}^{2+}$-calmodulin-dependent protein kinase which phosphorylates an endogenous protein of molecular weight 53,000 [6].

Since human islets contain calmodulin [23], and trifluoperazine inhibits glucose-induced insulin release from human islets [8], we examined extracts of human islets for $\mathrm{Ca}^{2+}$-calmodulin-dependent protein kinases. Myosin light chain kinase was demonstrated in the presence of exogenous myosin light chains; a second $\mathrm{Ca}^{2+}$-calmodulin-dependent protein kinase was demonstrated by stimulation of phosphorylation of a 48-kDal endogenous polypeptide in the presence of $\mathrm{Ca}^{2+}$ and calmodulin. This phosphoprotein substrate is similar in molecular weight to the 53-kDal substrate found in rat islets; however, whether these two phosphoproteins are related remains to be determined.

Due to the limited amount of material available, it was not possible to investigate whether the islet extracts also contained $\mathrm{Ca}^{2+}$-phospholipid-dependent protein kinase. However, we did observe that calcium stimulated phosphorylation of two other endogenous polypeptides (molecular weights of approximately 20 and 100-kDal). Unlike the 48-kDal polypeptide, phosphorylation of these proteins was not stimulated by exogenous calmodulin, yet trifluoperazine inhibited their phosphorylation. This could be explained either by the fact that there was sufficient endogenous calmodulin in the incubation or, since trifluoperazine also inhibits $\mathrm{Ca}^{2+}$-phospholipid-dependent protein kinase [18], these phosphorylations may have been catalysed by the $\mathrm{Ca}^{2+}$-phospholipid-dependent protein kinase. Confirmation of the latter possibility would require further experiments examining the stimulatory effects of diacylglycerol and phosphatidylserine on phosphorylation of these proteins.

These data provide, for the first time, evidence for the existence of $\mathrm{Ca}^{2+}$-dependent-protein kinases in human islets, and lend support to the hypothesis that protein phosphorylation is a regulator of stimulus-secretion coupling in the human, as well as the rodent, pancreatic $\beta$ cell.

Acknowledgements. The work described was supported by grants from the British Diabetic Association, Kroc Foundation and The Medical Research Council. D.E.H. is an R.D. Lawrence Fellow of the British Diabetic Association. We would also like to thank Dr. S.J.H. Ashcroft for useful discussion.

\section{References}

1. Gray DWR, McShane P, Grant AM, Morris PJ (1984) A method for isolation of islets of Langerhans from the human pancreas. Diabetes 33: 1055-1061

2. Krebs HA, Henseleit K (1932) Untersuchungen über die Harnstoffbildung im Tierkörper. Hoppe-Seylers Z Physiol Chem 210: 33-63

3. Ashcroft SJH, Crossley JR (1975) Effects of glucose, N-acetylglucosamine, glyceraldehyde and other sugars on insulin release in vivo. Diabetologia 11: 274-279

4. Ashcroft SJH, Hedeskov CJ, Randle PJ (1970) Glucose metabolism in mouse pancreatic islets. Biochem J 118: 143-154 
5. Laemmli, UK (1970) Cleavage of structural proteins during the assembly of the head of bacteriophage T4. Nature 227:680-685

6. Harrison DE, Ashcroft SJH (1982) Effects of $\mathrm{Ca}^{2+}$, calmodulin and cyclic AMP on the phosphorylation of endogenous proteins by homogenates of rat islets of Langerhans. Biochim Biophys Acta $714:$ :313-319

7. Sener A, Kawazu S, Hutton JC, Boschero AC, Devis G, Somers G, Herchueltz A, Malaisse WJ (1978) The stimulus-secretion coupling of glucose induced insulin release. Effect of exogenous pyruvate on islet function. Biochem J 176: 217-232

8. Grant AM, Christie MR, Ashcroft SJH (1980) Insulin release from human pancreatic islets in vitro. Diabetologia 19: 114-117

9. Ashcroft SJH, Bassett JM, Randle PJ (1971) Isolation of human pancreatic islets capable of releasing insulin and metabolizing glucose in vitro. Lancet 1:888-889

10. Andersson A, Borg H, Groth C-G, Gunnarsson R, Hellerström C, Lundgren G, Westman J, Östman J (1976) Survival of isolated human islets of Langerhans maintained in tissue culture. J Clin Invest 57: 1295-1301

11. Lohmann D, Jahr H, Verlohren H-J, Schmidt S, Heilmann W, Zuhlke H, Hartig W, Mattig H (1980) Insulin secretion in maturity-onset diabetes. Function of isolated islets. Horm Metab Res 12: $349-353$

12. Ashcroft SJH (1980) Glucoreceptor mechanisms and the control of insulin release and biosynthesis. Diabetologia 18: 5-15

13. Cahill GF, Herrera MG, Morgan AP, Soelder JS, Steinke J, Levy PL, Reichard GA, Kipnis DM (1966) Hormone-fuel interrelationships during fasting. J Clin Invest 45: 1751-1769

14. Williams IH, Ashcroft SJH (1978) $\mathrm{N}$-acetylglucosamine and the substrate-site hypothesis for the control of insulin biosynthesis and secretion. FEBS Lett 87: 115-120

15. Wollheim CB, Sharp GWG (1981) Regulation of insulin release by calcium. Physiol Rev 61: 914-973

16. Sugden MC, Christie MR, Ashcroft SJH (1979) Presence and possible role of calcium-dependent regulator (calmodulin) in rat islets of Langerhans. FEBS Letts 105: 95-100
17. Gagliardino JJ, Harrison DE, Christie MR, Gagliardino EE, Ashcroft SJH (1980) Evidence for the participation of calmodulin in stimulus-secretion coupling in the pancreatic $\beta$-cell. Biochem $\mathbf{J}$ 192: 919-927

18. Schatzman RC, Wise BC, Kuo JF (1981) Phospholipid-sensitive calcium-dependent protein kinase: inhibition by antipsychotic drugs. Biochem Biophys Res Commun 98: 669-676

19. Lord JM, Ashcroft SJH (1984) Identification and characterization of $\mathrm{Ca}^{2+}$-phospholipid-dependent protein kinase in rat islets and hamster $\beta$-cells. Biochem J 219: 547-551

20. Harrison DE, Ashcroft SJH (1982) Phosphorylation-dephosphorylation mechanisms and insulin secretion: $\mathrm{Ca}^{2+}$-dependent enzymes of protein and phospholipid metabolism in rat islets of Langerhans. Diabetologia 23: 172-173

21. Penn EJ, Brocklehurst KW, Sopwith AM, Hales CN, Hutton JC (1982) $\mathrm{Ca}^{2+}$-calmodulin dependent myosin light chain phosphorylating activity in insulin-secreting tissues. FEBS Letts 139:4-8

22. MacDonald MJ, Kowluru A (1982) $\mathrm{Ca}^{2+}$-calmodulin dependent myosin phosphorylation by pancreatic islets. Diabetes 31: $566-570$

23. Grant AM (1984) Developmental, functional and immunological aspects of human islets of Langerhans. D. Phil. Thesis, University of Oxford

Received: 12 June 1984

and in revised form: 23 November 1984

Dr. D. E. Harrison

Nuffield Department of Clinical Biochemistry

John Radcliffe Hospital

Headington

Oxford, OX3 9DU

UK 